\title{
Diversity and abundance of arboreal psocids (Psocoptera) along latitudinal gradients in northern Europe
}

\author{
JusSI KANERVO ${ }^{1}$ and MiKhaIL V. KOZLOV ${ }^{2 *}$ \\ ${ }^{1}$ Zoological Museum, University of Turku, 20014 Turku, Finland; e-mail: jussi.kanervo@luukku.com \\ ${ }^{2}$ Section of Ecology, University of Turku, 20014 Turku, Finland; e-mail: mikoz@utu.fi
}

Key words. Psocoptera, abundance, diversity, latitudinal gradients, northern Europe, Picea abies, Pinus sylvestris, Betula pendula, Betula pubescens

\begin{abstract}
Psocids are small insects that feed primarily on fungi, algae, lichens and organic detritus. Although they are relatively common in forest ecosystems, the general patterns in their abundance and diversity in boreal forests are still poorly known. We report records of 20 species of psocids quantitatively collected from four species of woody plants (Pinus sylvestris, Picea abies, Betula pubescens and $B$. pendula) at 50 sites in northern Europe, located between $59^{\circ}$ and $70^{\circ} \mathrm{N}$ and between $10^{\circ}$ and $60^{\circ} \mathrm{E}$. Seven species were found only on conifers, seven other species only on birches and six species inhabited both birches and conifers. The overall density of psocids was $18.9 \pm 2.9 \mathrm{exx} / \mathrm{kg}$ (d.w. of plant material). Densities varied among the studied species of trees, being highest on $P$. abies and lowest on $B$. pendula. The species diversity was highest on $B$. pendula and lowest on $B$. pubescens. Both diversity and abundance of arboreal psocids in northern Europe decreased with latitude. However, due to the relatively low number of specimens collected, the conclusions about the diversity of psocids should be seen as tentative.
\end{abstract}

\section{INTRODUCTION}

Psocids are small insects that feed primarily on fungi, algae, lichens and organic detritus. They are relatively common in forest ecosystems, being an important component of arthropod communities in the canopies (Thornton, 1985; Halaj et al., 2000; Thunes et al., 2004). Although in some regions, in particular in Fennoscandia, the ecology of psocids is studied relatively well (Laine et al., 1993; Kanervo \& Várkonyi, 2007), the general patterns in their abundance and diversity in boreal forests are still poorly known. Therefore our first goal was to quantify the abundance and diversity of arboreal psocids inhabiting the main forest-forming trees in northern Europe (Scots pine, Pinus sylvestris L.; Norway spruce, Picea abies (L.) Karst.; downy birch, Betula pubescens Ehrh.; white birch, B. pendula Roth.).

Exploration of different characteristics of terrestrial ecosystems along latitudinal gradients (used as surrogates for changes in temperature and precipitation) has recently become increasingly popular (Willig et al., 2003; Adams et al., 2010; Moles et al., 2011; Kozlov et al., 2013). The detected latitudinal patterns, with some limitations, can be used to predict how ecosystem characteristics will change as climate warms. We are not aware of any study exploring changes in communities of arboreal psocids along latitudinal gradients. Therefore our second goal was to search for latitudinal patterns in both abundance and diversity of arboreal psocids in boreal forests of northern Europe.

In contrast to Western Europe, the psocid fauna of which is relatively well studied, information on psocids of the northern parts of European Russia is rather limited. Reuter (1893) mentioned the occurrence of several species in the area which now belongs to the Republic of Karelia. Recent faunistic inventories were restricted to Leningrad oblast (Saveliev, 1997, 1999; Golub, 1999). A few species were occasionally recorded from the Republics of Karelia and Komi (Danka, 1968; Humala, 2006), but we were unable to find any records of psocids collected in the Murmansk, Arkhangelsk or Vologda regions of Russia. Therefore our third goal was to improve the knowledge on the distribution of arboreal psocids in north-eastern Europe.

\section{MATERIAL AND METHODS}

Sampling was conducted along five latitudinal gradients (Fig. 1: $\mathrm{N}$ - in Norway; F - mostly within Finland; R - in Russia between St. Petersburg and Murmansk; A - in Russia between Vologda and Arkhangelsk; K - in Russia between Vologda and Inta). All gradients were located in Scandinavian and Russian taiga, an eco-region within the taiga and boreal forests biome. Typical coniferous forests in this region are dominated by Scots pine or Norway spruce with a significant admixture of downy and white birches. The study sites were located in forests typical for each locality; the care was taken to select a representative site where all four species of forest-forming trees (mentioned above) grow naturally. In some situations this was impossible, and therefore in 13 of 50 study sites we collected samples from three species of trees, and in two sites from two species of trees (Table 1). Each site was sampled twice a year $(\mathrm{N}$ gradient: 29.vi.-2.vii. and 27.-30.viii.2011; F gradient: 25.-26.vi. and 2.-4.ix.2008; R gradient: 23.-29.vii. and 21.-25.viii.2008, 24.-29.vi. and 24.-28.viii.2009, 22.-27.vi. and 29.vii.2.viii.2010, 12.-16.vi. and 10.-14.viii.2011; A gradient:

\footnotetext{
* Corresponding author.
} 


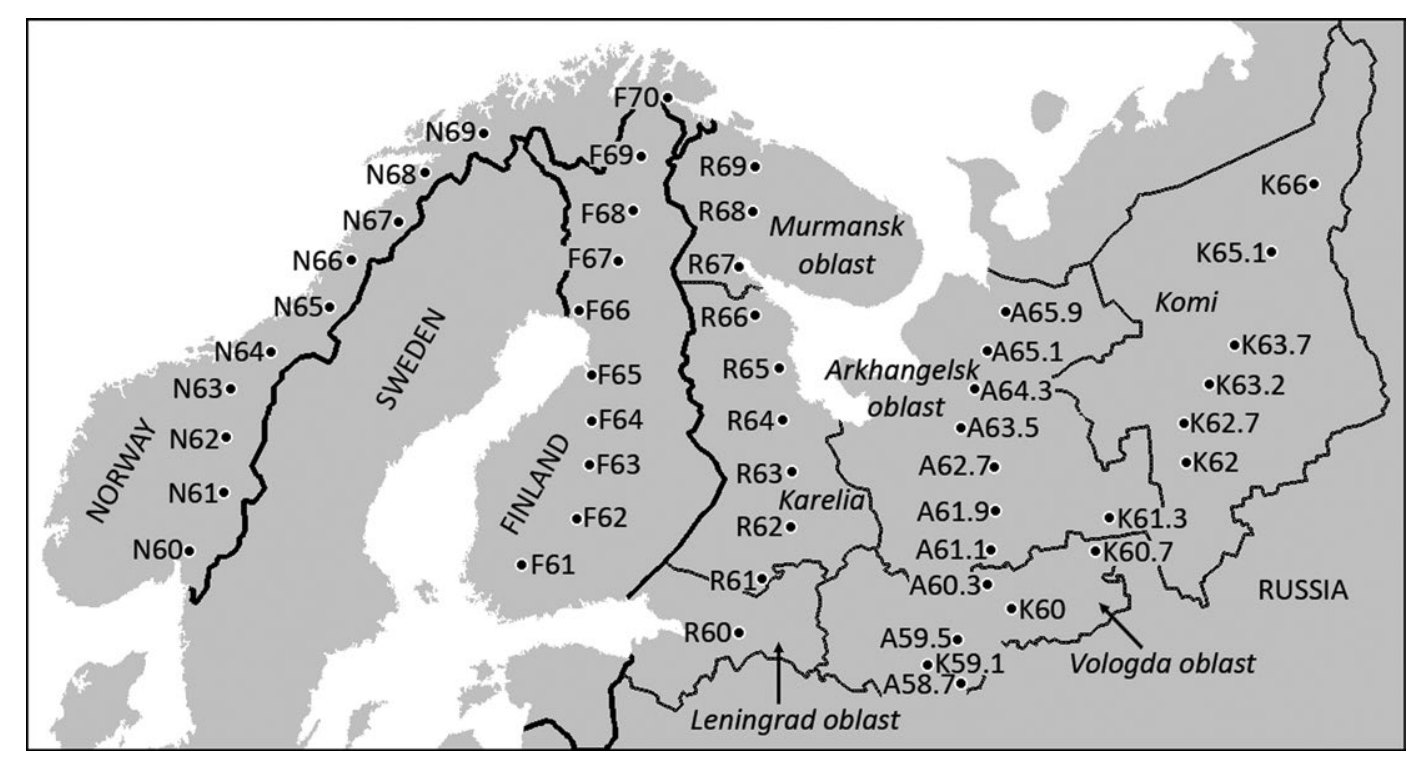

Fig. 1. Locations of the study sites.

16.-18.vi. and 7.-9.viii.2010; $\mathrm{K}$ gradient: 18.-20.vi. and 1.-3.ix.2009).

Mature trees (generally aged 20 or more years) with accessible (i.e., within $2 \mathrm{~m}$ above the ground) lower branches were selected on a "first found, first sampled" basis. At each site samples were collected from five trees of each species on each sampling date. The sampled trees were not tagged, and therefore early and late summer samples were generally collected from different trees. One branch (that can be accessed without disturbing the insects feeding on it) of about $50 \mathrm{~cm}$ in length (with approximately 80 leaves on birches, or 500 needle pairs on Scots pine, or 4000 needles on spruce) was selected on each sampled tree. One of two collectors placed a mesh bag attached to a ring $(60 \mathrm{~cm}$ in diameter) under the selected branch, after which, the second collector cut the branch in such a way that it fell into the bag together with the insects that dropped from the branch when disturbed. The average temperature at the time of sampling was $16.2^{\circ} \mathrm{C}$ and it is unlikely that many psocids escaped by flying. The bag was immediately closed, labelled and transported to the laboratory where all invertebrates were collected and preserved in alcohol. All fully developed adults and some nymphs of psocids were identified by J. Kanervo using both external characters and structure of genitalia; psocid nomenclature follows Svensson \& Hall (2010). Voucher specimens were deposited in the Zoological Museum of the University of Turku, Finland.

The collected branches were dried at $+80^{\circ} \mathrm{C}$ for $48 \mathrm{~h}$ and weighed; abundance of psocids was expressed in exx $/ \mathrm{kg}$ (d.w.) of branch, including both woody parts and foliage. To allow the direct comparison of our data with published estimates of psocid density, we transformed the latter values to specimens per $1 \mathrm{~kg}$ of dry weight of medium-sized branches by using the data on specific leaf weights of sampled plants and assuming that the foliage comprises $20 \%$ of dry weight of a branch. As a measure of diversity, we used the number of species in a random sample of 15 individuals, calculated from our data using individualbased rarefaction.

Distribution of psocids both on individual branches and at different study sites was greatly skewed and therefore we used non-parametric methods to analyse these data. The abundance of psocids was compared among gradients, tree species and study years using Kruskal-Wallis test; latitudinal patterns in both abundance and diversity were explored by calculating Spearman rank correlation coefficients with latitudes of study sites (SAS Institute, 2009). Rarefaction-based estimates of species richness were compared with $t$-test

\section{RESULTS}

\section{Overall abundance}

A total of 607 psocids were found in 298 samples; 2692 samples did not contain psocids. The number of individuals in a sample varied from 1 to 21 (with a median value of 1); 163 samples contained adults. An overall abundance of psocids (all sites and tree species pooled) was (mean \pm S.E.) $18.9 \pm 2.9 \mathrm{exx} / \mathrm{kg}$ (d.w.).

\section{Association of psocids with different species of trees}

Densities of psocids varied among the surveyed tree species (Kruskal-Wallis test: $\chi^{2}=50.4, d f=3, P<$ 0.0001 ), being highest on $P$. abies and lowest on $B$. pendula (Fig. 2a). Of the 20 collected species, seven were found only on conifers, seven only on birches and six species on both conifers and birches (Table 2). The species diversity was highest on $B$. pendula and lowest on $B$. pubescens (Fig. 2b).

\section{Geographical variation in abundance and diversity}

Densities of psocids differed among the five latitudinal gradients (Kruskal-Wallis test: $\chi^{2}=34.8, d f=4, P<$ 0.0001 ), being highest in the $\mathrm{R}$ gradient and lowest in the A gradient (Fig. 3a). This pattern probably reflects geographical variation rather than variation among the study years, because the overall abundance of psocids in the $\mathrm{R}$ gradient did not change over the period 2008-2011 (Fig. $\left.3 \mathrm{~b} ; \chi^{2}=5.56, d f=3, P=0.14\right)$.

In the $\mathrm{R}$ gradient, densities of psocids varied among the study sites $\left(\chi^{2}=24.9, d f=9, P=0.003\right)$, although this variation was not explained by the latitudes of the study sites $\left(r_{\mathrm{S}}=-0.30, n=10\right.$ sites, $\left.P=0.40\right)$. Among individual species, only Peripsocus phaeopterus and P. subfasciatus demonstrated significant decrease in abundance 
TABLE 1. Geographical coordinates of study sites and numbers of specimens of arboreal psocids collected from different species of trees at each site.

\begin{tabular}{|c|c|c|c|c|c|c|c|c|}
\hline \multirow{2}{*}{ Study site } & \multirow{2}{*}{ Country $^{1}$} & \multirow{2}{*}{$\begin{array}{c}\text { Region or } \\
\text { provenance }^{2}\end{array}$} & \multicolumn{2}{|c|}{ Coordinates } & \multicolumn{4}{|c|}{ Numbers of specimens ${ }^{3}$} \\
\hline & & & Latitude, $\mathrm{N}$ & Longitude, $\mathrm{E}$ & syl & $a b i$ & pen & pub \\
\hline N60 & NOR & $\mathrm{AK}$ & $59^{\circ} 47^{\prime} 34^{\prime \prime}$ & $10^{\circ} 45^{\prime} 35^{\prime \prime}$ & 0 & 0 & 1 & 24 \\
\hline N61 & NOR & $\mathrm{HE}$ & $61^{\circ} 04^{\prime} 40^{\prime \prime}$ & $11^{\circ} 20^{\prime} 46^{\prime \prime}$ & 0 & 0 & 0 & 0 \\
\hline N62 & NOR & $\mathrm{HE}$ & $62^{\circ} 04^{\prime} 19^{\prime \prime}$ & $10^{\circ} 42^{\prime} 40^{\prime \prime}$ & 0 & 1 & - & 0 \\
\hline N63 & NOR & $\mathrm{ST}$ & $62^{\circ} 59^{\prime} 28^{\prime \prime}$ & $10^{\circ} 15^{\prime} 50^{\prime \prime}$ & 0 & 1 & 0 & 3 \\
\hline N64 & NOR & NT & $63^{\circ} 54^{\prime} 15^{\prime \prime}$ & $11^{\circ} 26^{\prime} 25^{\prime \prime}$ & 0 & 0 & - & 1 \\
\hline N65 & NOR & NT & $65^{\circ} 04^{\prime} 19^{\prime \prime}$ & $13^{\circ} 18^{\prime} 15^{\prime \prime}$ & 0 & 0 & - & 0 \\
\hline N66 & NOR & Ns & $66^{\circ} 02^{\prime} 56^{\prime \prime}$ & $13^{\circ} 36^{\prime} 32^{\prime \prime}$ & 0 & 4 & - & 0 \\
\hline N67 & NOR & Ns & $66^{\circ} 59^{\prime} 44^{\prime \prime}$ & $15^{\circ} 20^{\prime} 22^{\prime \prime}$ & 1 & 3 & - & 0 \\
\hline N68 & NOR & $\mathrm{Nn}$ & $68^{\circ} 02^{\prime} 26^{\prime \prime}$ & $15^{\circ} 58^{\prime} 32^{\prime \prime}$ & 0 & 1 & - & 0 \\
\hline N69 & NOR & TR & $68^{\circ} 59^{\prime} 30^{\prime \prime}$ & $18^{\circ} 30^{\prime} 51^{\prime \prime}$ & 1 & 12 & - & 0 \\
\hline F61 & FIN & $\mathrm{Ta}$ & $61^{\circ} 00^{\prime} 27^{\prime \prime}$ & $23^{\circ} 30^{\prime} 42^{\prime \prime}$ & 4 & 22 & 1 & 2 \\
\hline F62 & FIN & $\mathrm{Ta}$ & $62^{\circ} 00^{\prime} 06^{\prime \prime}$ & $25^{\circ} 31^{\prime} 30^{\prime \prime}$ & 0 & 5 & 0 & 0 \\
\hline F63 & FIN & $\mathrm{Tb}$ & $63^{\circ} 03^{\prime} 14^{\prime \prime}$ & $25^{\circ} 49^{\prime} 33^{\prime \prime}$ & 0 & 7 & 0 & 0 \\
\hline F64 & FIN & $\mathrm{Om}$ & $63^{\circ} 53^{\prime} 48^{\prime \prime}$ & $25^{\circ} 47^{\prime} 52^{\prime \prime}$ & 0 & 5 & 2 & 0 \\
\hline F65 & FIN & Oba & $64^{\circ} 45^{\prime} 47^{\prime \prime}$ & $25^{\circ} 34^{\prime} 09^{\prime \prime}$ & 0 & 1 & - & 0 \\
\hline F66 & FIN & Obb & $65^{\circ} 58^{\prime} 32^{\prime \prime}$ & $24^{\circ} 39^{\prime} 49^{\prime \prime}$ & 0 & 1 & 0 & 0 \\
\hline F67 & FIN & $\mathrm{Obb}$ & $66^{\circ} 58^{\prime} 49^{\prime \prime}$ & $26^{\circ} 19^{\prime} 32^{\prime \prime}$ & 0 & 9 & 0 & 1 \\
\hline F68 & FIN & Lkor & $67^{\circ} 58^{\prime} 35^{\prime \prime}$ & $26^{\circ} 50^{\prime} 53^{\prime \prime}$ & 1 & 0 & 0 & 0 \\
\hline F69 & FIN & $\mathrm{Li}$ & $69^{\circ} 00^{\prime} 41^{\prime \prime}$ & $27^{\circ} 00^{\prime} 39^{\prime \prime}$ & 1 & - & 0 & 0 \\
\hline F70 & NOR & $\mathrm{F}$ & $70^{\circ} 04^{\prime} 41^{\prime \prime}$ & $27^{\circ} 59^{\prime} 22^{\prime \prime}$ & 0 & 0 & - & 0 \\
\hline R60 & RUS & Le & $59^{\circ} 58^{\prime} 26^{\prime \prime}$ & $32^{\circ} 11^{\prime} 46^{\prime \prime}$ & 15 & 85 & 8 & 13 \\
\hline R61 & RUS & $\mathrm{Ka}$ & $61^{\circ} 00^{\prime} 03^{\prime \prime}$ & $33^{\circ} 03^{\prime} 41^{\prime \prime}$ & 4 & 27 & 1 & 8 \\
\hline R62 & RUS & $\mathrm{Ka}$ & $61^{\circ} 58^{\prime} 51^{\prime \prime}$ & $34^{\circ} 14^{\prime} 27^{\prime \prime}$ & 13 & 8 & 4 & 9 \\
\hline R63 & RUS & $\mathrm{Ka}$ & $63^{\circ} 00^{\prime} 07^{\prime \prime}$ & $34^{\circ} 22^{\prime} 55^{\prime \prime}$ & 1 & 16 & 1 & 2 \\
\hline R64 & RUS & $\mathrm{Ka}$ & $64^{\circ} 01^{\prime} 44^{\prime \prime}$ & $34^{\circ} 04^{\prime} 11^{\prime \prime}$ & 12 & 36 & 6 & 5 \\
\hline R65 & RUS & $\mathrm{Ka}$ & $65^{\circ} 01^{\prime} 25^{\prime \prime}$ & $34^{\circ} 00^{\prime} 40^{\prime \prime}$ & 1 & 19 & 2 & 1 \\
\hline R66 & RUS & $\mathrm{Ka}$ & $66^{\circ} 01^{\prime} 57^{\prime \prime}$ & $32^{\circ} 59^{\prime} 13^{\prime \prime}$ & 16 & 36 & 0 & 2 \\
\hline R67 & RUS & $\mathrm{Mu}$ & $66^{\circ} 56^{\prime} 04^{\prime \prime}$ & $32^{\circ} 12^{\prime} 24^{\prime \prime}$ & 0 & 41 & 0 & 5 \\
\hline R68 & RUS & $\mathrm{Mu}$ & $68^{\circ} 01^{\prime} 05^{\prime \prime}$ & $32^{\circ} 57^{\prime} 07^{\prime \prime}$ & 2 & 2 & 4 & 5 \\
\hline R69 & RUS & $\mathrm{Mu}$ & $68^{\circ} 52^{\prime} 34^{\prime \prime}$ & $33^{\circ} 07^{\prime} 42^{\prime \prime}$ & 4 & 21 & - & 14 \\
\hline A58.7 & RUS & Vo & $58^{\circ} 40^{\prime} 55^{\prime \prime}$ & $40^{\circ} 18^{\prime} 35^{\prime \prime}$ & - & 1 & 0 & 0 \\
\hline A59.5 & RUS & Vo & $59^{\circ} 32^{\prime} 17^{\prime \prime}$ & $40^{\circ} 25^{\prime} 20^{\prime \prime}$ & 0 & 2 & 0 & 0 \\
\hline A 60.5 & RUS & Vo & $60^{\circ} 29^{\prime} 04^{\prime \prime}$ & $41^{\circ} 48^{\prime} 50^{\prime \prime}$ & 0 & 2 & 0 & 0 \\
\hline A61.1 & RUS & $\mathrm{Ar}$ & $61^{\circ} 08^{\prime} 22^{\prime \prime}$ & $42^{\circ} 11^{\prime} 40^{\prime \prime}$ & 0 & 2 & 0 & 0 \\
\hline A61.9 & RUS & $\mathrm{Ar}$ & $61^{\circ} 51^{\prime} 49^{\prime \prime}$ & $42^{\circ} 38^{\prime} 01^{\prime \prime}$ & 0 & 2 & 0 & 0 \\
\hline A62.7 & RUS & $\mathrm{Ar}$ & $62^{\circ} 41^{\prime} 52^{\prime \prime}$ & $42^{\circ} 53^{\prime} 35^{\prime \prime}$ & 0 & 5 & 0 & 0 \\
\hline A63.5 & RUS & $\mathrm{Ar}$ & $63^{\circ} 30^{\prime} 59^{\prime \prime}$ & $41^{\circ} 42^{\prime} 55^{\prime \prime}$ & 0 & 0 & 0 & 0 \\
\hline A64.2 & RUS & $\mathrm{Ar}$ & $64^{\circ} 13^{\prime} 25^{\prime \prime}$ & $42^{\circ} 37^{\prime} 44^{\prime \prime}$ & 0 & 0 & 0 & 0 \\
\hline A64.9 & RUS & $\mathrm{Ar}$ & $64^{\circ} 54^{\prime} 21^{\prime \prime}$ & $43^{\circ} 31^{\prime} 03^{\prime \prime}$ & 0 & 0 & 0 & 1 \\
\hline A65.6 & RUS & $\mathrm{Ar}$ & $65^{\circ} 34^{\prime} 27^{\prime \prime}$ & $44^{\circ} 37^{\prime} 35^{\prime \prime}$ & 0 & 0 & - & 0 \\
\hline K59.1 & RUS & Vo & $59^{\circ} 07^{\prime} 31^{\prime \prime}$ & $39^{\circ} 11^{\prime} 26^{\prime \prime}$ & 2 & 4 & 0 & 1 \\
\hline K60 & RUS & Vo & $59^{\circ} 57^{\prime} 11^{\prime \prime}$ & $42^{\circ} 37^{\prime} 07^{\prime \prime}$ & 2 & 7 & 0 & 0 \\
\hline K60.7 & RUS & Vo & $60^{\circ} 43^{\prime} 13^{\prime \prime}$ & $46^{\circ} 14^{\prime} 51^{\prime \prime}$ & 0 & 2 & 0 & 1 \\
\hline K61.3 & RUS & $\mathrm{Ar}$ & $61^{\circ} 16^{\prime} 35^{\prime \prime}$ & $47^{\circ} 04^{\prime} 04^{\prime \prime}$ & 1 & 1 & 0 & 0 \\
\hline K62 & RUS & $\mathrm{Km}$ & $61^{\circ} 55^{\prime} 37^{\prime \prime}$ & $50^{\circ} 40^{\prime} 47^{\prime \prime}$ & 0 & 0 & 0 & 0 \\
\hline K62.7 & RUS & $\mathrm{Km}$ & $62^{\circ} 38^{\prime} 42^{\prime \prime}$ & $51^{\circ} 03^{\prime} 52^{\prime \prime}$ & 0 & 2 & 0 & 1 \\
\hline K63.2 & RUS & $\mathrm{Km}$ & $63^{\circ} 11^{\prime} 32^{\prime \prime}$ & $52^{\circ} 38^{\prime} 30^{\prime \prime}$ & 0 & 0 & 0 & 0 \\
\hline K63.7 & RUS & $\mathrm{Km}$ & $63^{\circ} 44^{\prime} 14^{\prime \prime}$ & $54^{\circ} 12^{\prime} 43^{\prime \prime}$ & 0 & 0 & 0 & 0 \\
\hline K65.1 & RUS & $\mathrm{Km}$ & $65^{\circ} 08^{\prime} 33^{\prime \prime}$ & $57^{\circ} 16^{\prime} 22^{\prime \prime}$ & 0 & 4 & - & 0 \\
\hline K66 & RUS & $\mathrm{Km}$ & $66^{\circ} 00^{\prime} 16^{\prime \prime}$ & $60^{\circ} 20^{\prime} 14^{\prime \prime}$ & 0 & - & - & 0 \\
\hline
\end{tabular}

${ }^{1}$ FIN - Finland; NOR - Norway; RUS - Russia. ${ }^{2}$ Regions of Russia: Ar - Arkhangelsk oblast; Ka - Republic of Kareila; Km Republic of Komi; Le - Leningrad oblast; Mu - Murmansk oblast; Vo - Vologda oblast. Abbreviations of the provenances of Finland and Norway follow Heie (1995). ${ }^{3}$ Species of trees: syl-Pinus sylvestris; abi-Picea abies; pen - Betula pendula; pub - Betula pubescens. Dash indicates absence of this species of tree at the study site. 
TABLE 2. Distribution of arboreal psocids among the studied tree species.

\begin{tabular}{|c|c|c|c|c|c|c|}
\hline \multirow{2}{*}{ Family } & \multirow{2}{*}{ Species } & \multicolumn{5}{|c|}{ Numbers of specimens $^{1}$} \\
\hline & & syl & $a b i$ & pen & pub & Total \\
\hline \multirow{7}{*}{ Caeciliusidae } & Caecilius fuscopterus (Latreille) & 2 & 0 & 2 & 2 & 6 \\
\hline & Valenzuela flavidus (Stephens) & 2 & 10 & 6 & 27 & 45 \\
\hline & V. burmeisteri (Brauer) & 6 & 49 & 0 & 0 & 55 \\
\hline & $V$. piceus (Kolbe) & 0 & 8 & 0 & 0 & 8 \\
\hline & V. gynapterus (Tetens) & 0 & 0 & 0 & 1 & 1 \\
\hline & $V$. despaxi (Badonnel) & 1 & 1 & 0 & 0 & 2 \\
\hline & Enderleinella obsoleta (Stephens) & 0 & 14 & 0 & 0 & 14 \\
\hline \multirow{2}{*}{ Stenopsocidae } & Stenopsocus immaculatus (Stephens) & 0 & 0 & 2 & 0 & 2 \\
\hline & S. lachlani Kolbe & 3 & 16 & 1 & 1 & 21 \\
\hline \multirow{2}{*}{ Peripsocidae } & Peripsocus phaeopterus (Stephens) & 1 & 2 & 1 & 4 & 8 \\
\hline & P. subfasciatus (Rambur) & 2 & 21 & 1 & 3 & 27 \\
\hline \multirow{2}{*}{ Elipsocidae } & Elipsocus abdominalis Reuter & 0 & 0 & 2 & 0 & 2 \\
\hline & Hemineura dispar Tetens & 0 & 0 & 1 & 1 & 2 \\
\hline Philotarsidae & Philotarsus sp. & 0 & 1 & 0 & 0 & 1 \\
\hline \multirow{2}{*}{ Mesopsocidae } & Mesopsocus unipunctatus (Müller) & 0 & 0 & 0 & 2 & 2 \\
\hline & M. immunis (Stephens) & 0 & 0 & 0 & 1 & 1 \\
\hline \multirow{4}{*}{ Psocidae } & Metylophorus nebulosus (Stephens) & 4 & 3 & 4 & 2 & 13 \\
\hline & Psococerastis gibbosa (Sulzer) & 0 & 0 & 1 & 0 & 1 \\
\hline & Trichadenotecnum majus (Kolbe) & 0 & 1 & 0 & 0 & 1 \\
\hline & T. incognitum Roesler & 0 & 4 & 0 & 0 & 4 \\
\hline \multicolumn{2}{|c|}{ Not identified (juveniles and damaged specimens) } & 60 & 267 & 9 & 55 & 391 \\
\hline \multicolumn{2}{|c|}{ Total number of specimens } & 81 & 397 & 30 & 99 & 607 \\
\hline \multicolumn{2}{|c|}{ Total number of species } & 8 & 12 & 10 & 10 & 20 \\
\hline
\end{tabular}

${ }^{1}$ Species of trees: syl-Pinus sylvestris; abi-Picea abies; pen-Betula pendula; pub-Betula pubescens.

with latitude $\left(r_{\mathrm{S}}=-0.70, n=10, P=0.02\right.$ and $r_{\mathrm{S}}=-0.80$, $P=0.01$, respectively). However, the densities of psocids in the southern half of the $\mathrm{R}$ gradient were on average nearly twice as high as in the northern half of the gradient $\left(36.6 \pm 13.0\right.$ and $20.6 \pm 11.1 \mathrm{exx} / \mathrm{kg}$, respectively; $\chi^{2}=$ 5.39, $d f=1, P=0.02)$.

The geographical variation in the diversity of arboreal psocids showed a similar pattern: although the number of recorded species did not correlate with the latitude of the study site $\left(r_{\mathrm{S}}=-0.48, n=10, P=0.40\right)$, the rarefactioncorrected estimate of species richness in the southern half of the $\mathrm{R}$ gradient was 1.36 times as high as in the northern half of it (mean \pm S.E. number of species in a sample of 15 individuals: $7.23 \pm 0.28$ and $5.30 \pm 0.27$, respectively; $t=4.95, P<0.001)$. When all five gradients were combined, the richness of psocid fauna decreased from 14 species between latitudes $59^{\circ}$ and $62^{\circ} \mathrm{N}$ to 10 species between latitudes $62^{\circ}$ and $66^{\circ} \mathrm{N}$ and 7 species between latitudes $66^{\circ}$ and $70^{\circ} \mathrm{N}$.

\section{DISCUSSION}

\section{Abundance and diversity of arboreal psocids}

The average density of psocids on 156 species of plants in south-eastern Australia amounted $0.3 \mathrm{exx} / \mathrm{m}^{2}$ of foliage (Woinarski \& Cullen, 1984), which is approximately equivalent to $1 \mathrm{exx} / \mathrm{kg}$ of branch. Fogging the canopies of Argyrodendron actinophyllum (Bailey) Edlin in the Aus- tralian rainforest yielded 40 exx of psocids $/ \mathrm{kg}$ of foliage (Basset \& Arthington, 1992), which is approximately equivalent to $10 \mathrm{exx} / \mathrm{kg}$ of branch. In dry evergreen forest in north-eastern Thailand insecticide fogging yielded 3-47 exx of procids per $1 \mathrm{~m}^{2}$ of trap size (Watanabe \& Ruaysoongnern, 1989), which is approximately equivalent to $1-15 \mathrm{exx} / \mathrm{kg}$ of branch. These values are in the same range as the density estimates obtained in coniferous forests in Oregon by sampling the branches of Douglas-fir, Pseudotsuga menziesii (Mirbel) Franco and Western hemlock, Tsuga heterophylla (Raf.) Sarg. In these samples, psocid density varied from 0.6 to 17 exx $/ \mathrm{kg}$ of branch (Schowalter, 1989, 1995). On the other hand, beating Douglas-fir branches in the same region resulted in a much higher estimate of abundance, 724 exx/kg (Halaj et al., 2000). Finally, sampling large (2 m long) branches from old Norway spruces in the surroundings of Oulu, northern Finland, revealed moderate density of psocids, approximately $23.4 \mathrm{exx} / \mathrm{kg}$, in contrast to 1.94 exx/kg on branches of young spruces (Laine et al., 1993). Thus, the density of arboreal psocids recorded in different studies varies by three orders of magnitude and the average density of psocids in our samples $(18.9 \mathrm{exx} / \mathrm{kg})$ is close to the median value obtained from the publications cited above.

One to 13 species of psocids were recorded from six species of trees in both Britain and South Africa using 

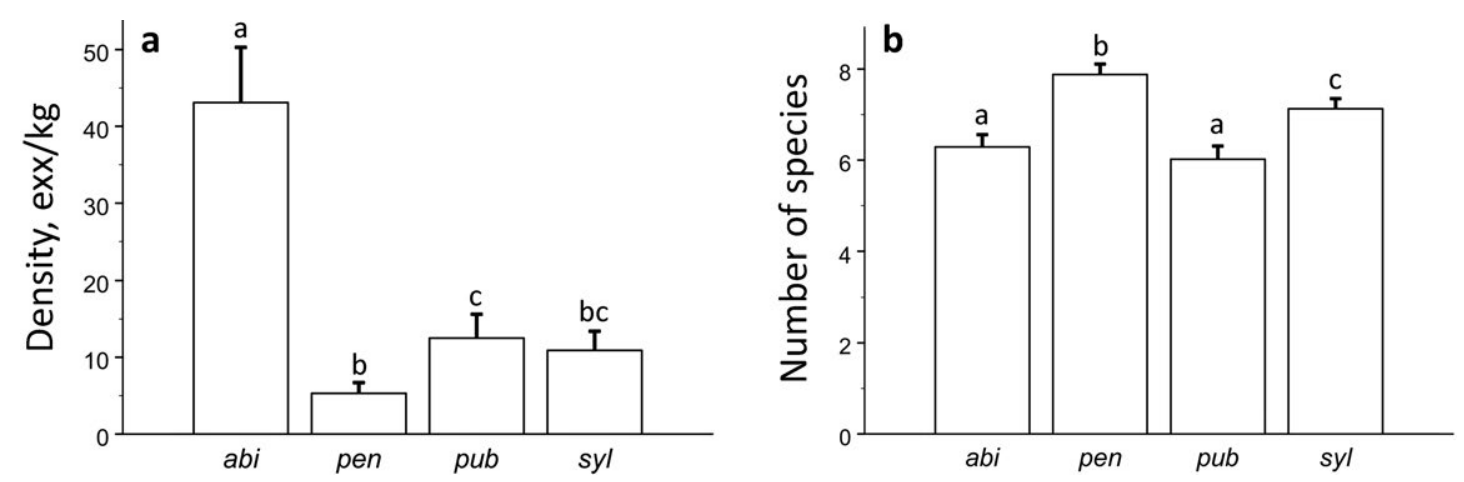

Fig. 2. Density (a) and number of species in a random sample of 15 individuals (b) of psocids found on different species of trees: abi-Picea abies; pen - Betula pendula; pub-B. pubescens; syl-Pinus sylvestris. Bars indicate standard errors; bars labelled with different letters differ from each other at the probability level $P=0.05$.

pyrethrum knockdown (Southwood et al., 1982). Unfortunately, the authors did not report sample sizes, which makes direct comparison with our data impossible. However, they collected 12 species of psocids from Betula sp. in the UK, which is nearly equal to the number of species we collected from $B$. pendula and B. pubescens in Northern Europe (13 species). On the other hand, New (1970) collected 9 species of psocids by beating twigs of 12 species of trees in the UK, from 2 to 9 species per studied tree species. Numbers of psocid species in a random sample of 15 individuals calculated using these data vary from 2.00 to 4.36 per tree species, i.e., are two to three times lower than in our samples. In particular, New (1970) reported only 4 species from $B$. pendula $(2.98 \pm 0.19$ species $/ 15 \mathrm{exx})$, in contrast to the 10 species collected in our study $(7.88 \pm 0.23$ species $/ 15$ exx $)$.

On the other hand, fogging resulted in collecting of 15 species of psocids from Scots pine canopies in southern Norway (Thunes et al., 2004), i.e., twice that we collected from Scots pine throughout northern Europe. Similarly, Laine et al. (1993) reported 16 species from old trees of Norway spruce whereas we collected only 12 species (Table 2). In both these studies, the higher richness of psocids resulted from sampling of species inhabiting bark of large branches and tree trunks (such as Trichadenotecnum majus and Reuterella helvimacula), which were rare or missing in the material we collected from small
(50 $\mathrm{cm}$ in length) branches. However, the numbers of species in a random sample of 15 individuals, based on the data from these publications, are $5.38 \pm 0.34$ and 5.82 \pm 0.29 , respectively, i.e., significantly lower than in our material (Fig. 2b). We attribute this difference to the greater geographical area surveyed in our study.

Our data (Table 2, Fig. 2b) support the conclusion (Thornton, 1985) on a similar diversity of "conifer species" and "broadleaved species" of psocids in northern Europe, and generally agree with data on species' preferences for particular tree species. The only exception is a high $(27 \%$ of the collected specimens) occurrence of $V$. flavidus on conifers (Table 2), because this species usually inhabits broadleaved trees (Svensson \& Hall, 2010); however, it was recorded from Norway spruce in Finland (Laine et al., 1993). As all foliage-frequenting psocids graze indiscriminately on microflora and debris on leaf surfaces their association with a particular tree species is explained by the physical characteristics of its foliage as a habitat for these minute insects (New, 1970).

\section{Geographical variation in psocid communities}

Thornton (1985) noted that psocid densities in tropics are much lower than in temperate forests. However, the diversity of methods used to collect the data, the shortage of studies and substantial variation in the abundance of psocids among different species of trees complicate the
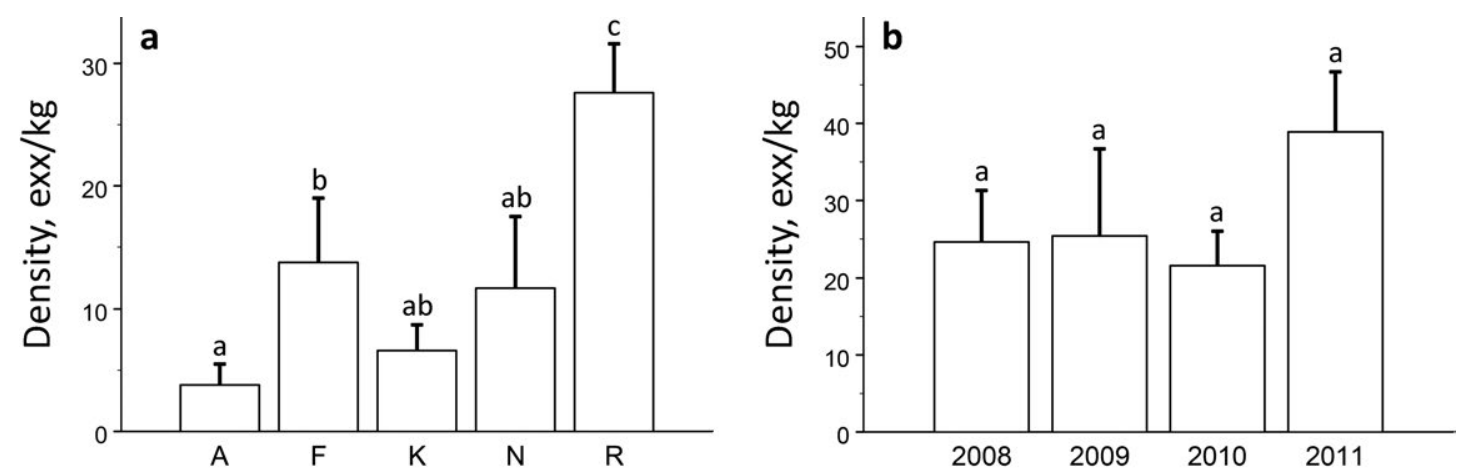

Fig. 3. Variation in density of arboreal psocids among the geographical regions (a) (A - between Vologda and Arkhangelsk, Russia; F - between Turku, Finland and Nuorgam, Norway; K - between Vologda and Inta, Russia; N - between Olso and Andselv, Norway; R - between St. Petersburg and Murmansk, Russia) and (b) among study years in the R gradient. Bars indicate standard errors; bars labelled with different letters differ from each other at the probability level $P=0.05$. 
use of published data for the analysis of latitudinal patterns. By using one sampling method, we demonstrated that densities of arboreal psocids in northern taiga forests decrease towards the North. In combination with the conclusions of Thornton (1985), our data hint at the existence of a dome-shaped latitudinal pattern, with the highest abundance of psocids occurring in temperate forests. Consequently, we hypothesize that the effects of climatic warming on arboreal psocids may depend on latitude: in boreal forests, the abundance of psocids is likely to increase, while in temperate forests it may decline.

The lower diversity of psocids recorded in the northern parts of our study region agrees with the general pattern (Willig et al., 2003) of a decrease in species richness from the equator towards the poles. We are not aware of any latitudinal comparisons of the diversity of arboreal psocids. Three studies of altitudinal climatic gradients revealed different patterns: diversity decreased with altitude in Switzerland (Lienhard, 1977), did not change with altitude in Sumatra (Kentjonowati \& New, 2004) and increased with altitude in Jamaica (Turner \& Broadhead, 1974). Keeping in mind the overall climatic differences between Switzerland and Jamaica, these data suggest that diversity of psocids, in parallel with their abundance, is likely to peak in regions with a temperate climate.

The differences between geographical gradients are more difficult to explain. We suggest that the high abundance recorded in the $\mathrm{R}$ gradient (from St. Petersburg to Murmansk) is due to the combination of humid (oceanic) climate, which is favourable for arboreal psocids (Alexander \& Saville, 2008), and the large proportion of oldgrown primary forests that still exist in this part of Russia. The forests in Finland and Norway are more intensively managed than those in Karelia and therefore they support less diverse insect faunas (Niemelä, 1997). The climate of both Arkhangelsk oblast and Republic of Komi is more continental (i.e., less humid) and nearly all the primary forests in our sampling areas were logged several decades ago.

The variation among the geographical regions, as well as among study sites in the $\mathrm{R}$ gradient, may result from a number of factors influencing the psocids, their food and habitats. None of these factors were recorded in the course of our study and therefore the mechanisms underlying the detected patterns remain unknown. Furthermore, due to the relatively low number of the collected specimens, the conclusions on the diversity of psocids should be seen as tentative.

\section{Completeness of faunistic inventory and interesting records}

Psocids collected in the course of ecological studies (e.g., Schowalter, 1995; Halaj et al., 2000; Andrew \& Hughes, 2005) are only rarely identified to the species level (but see Thunes et al., 2004) due to both shortage of taxonomic expertise and predominance of nymphs, which are difficult or even impossible to identify. But if the material collected primarily for testing ecological hypotheses is identified, then the question arises on whether this material is suitable for drawing faunistic or biogeographical conclusions, because the sampling methods used in ecological studies generally differ from those used for faunistic inventories.

We collected 20 species of psocids, i.e., $40 \%$ of those recorded on the same species of trees in Sweden and Finland (Svensson \& Hall, 2010; and pers. obs. by JK). Our samples are sufficiently representative of the species living mainly on foliage (we collected 9 of the 14 species known from Sweden and Finland, i.e., two-thirds of the potential fauna), but not of psocids that live mainly on the bark of branches and trunks (11 of 36 species, i.e., onethird of the potential fauna). On the other hand, beating thin branches and using window traps to collect psocids from different species of trees in Finland yielded 30 species (Kanervo \& Várkonyi, 2007), whereas we collected only 20 species. But this difference in species richness is likely to result from the higher number of identified specimens (2367, compared to 217 specimens in our study), rather than from the differences in the methods of psocid collection. Thus, our sampling method was not optimal for a faunistic study and the relatively low number of the collected specimens hampers biogeographical analysis of our data. In spite of this, we made several interesting records (see Appendix). In particular, Elipsocus abdominalis was for the first time recorded in Russia. We confirmed the occurrence of Hemineura dispar in the Republic of Karelia: this species was reported from Lahdenpohja (Jaakkima) by Reuter (1893) but not found by subsequent researchers. An infrequent species, Trichadenotecnum incognitum, earlier known from both the western (Romania, Switzerland, Austria, Czech Republic, Germany and Finland) and eastern Palaearctic (Primorye region of Russia and Japan), was found in Pechora, Republic of Komi. This is not only the first record from the European part of Russia, but also the northernmost record in Europe. In addition, our findings are the first contributions to the psocid fauna of the Murmansk (3 species), Arkhangelsk (2 species) and Vologda regions ( 5 species); they also increase the number of psocids recorded in the Republic of Karelia to 23 species and in the Republic of Komi to 7 species.

ACKNOWLEDGEMENTS. We thank V. Zverev, E. Zvereva, N. Zvereva, A. Popova, M. Inozemtseva, L. Krasheninin and V. Rinne for their assistance with both fieldwork and laboratory studies, C. Lienhard for checking the identifications of Elipsocus abdominalis and Trichadenotecnum incognitum, and E. Zvereva, G. Várkonyi, M. Konvicka, P. Svacha and two anonymous reviewers for commenting an earlier version of the manuscript. The study was supported by the Academy of Finland (project 122133 and researcher exchange grants) and by a strategic research grant from the University of Turku.

\section{REFERENCES}

Adams J.M., Brusa A., Soyeong A. \& Ainuddin A.N. 2010: Present-day testing of a paleoecological pattern: is there really a latitudinal difference in leaf-feeding insect-damage diversity? - Rev. Palaeobot. Palynol. 162: 63-70.

Alexander K.N.A. \& SAville R.E. 2008: Seven arboreal barkflies newly recognized in Ireland and records of other species 
from six historic demesnes across Northern Ireland (Insecta: Psocoptera) - Irish Natural. J. 29: 102-106.

Andrew N.R. \& Hughes L. 2005: Arthropod community structure along a latitudinal gradient: implications for future impacts of climate change. - Austral Ecol. 30: 281-297.

BASSET Y. \& ARTHINGTon A.H. 1992: The arthropod community of an Australian rain-forest tree - abundance of component taxa, species richness and guild structure. - Austral. J. Ecol. 17: 89-98.

DANKA L. 1968: Catalogue of the Psocoptera of the USSR. Latv. Entomol. 12: 3-18 [in Russian, English abstr.].

Golub N.V. 1999: Contribution to the knowledge of the fauna of psocids (Psocoptera) of Saint Petersburg and Leningrad province. - Entomol. Rev. 78: 324-326 [in Russian, English abstr.].

Halaj J., Ross D.W. \& Moldenke A.R. 2000: Importance of habitat structure to the arthropod food-web in Douglas-fir canopies. - Oikos 90: 139-152.

HeIE O.E. 1995: The Aphidoidea (Hemiptera) of Fennoscandia and Denmark. V. Family Aphididae: Part 3 of Tribe Macrosiphini of Subfamily Aphidinae, and family Lachnidae. Fauna Entomol. Scand. 31: 1-222.

Humala A.E. 2006: On the insect fauna of "Kivach" nature reserve. - Proc. Karelian Sci. Centre 10: 153-159 [in Russian, English abstr.].

Kanervo J. \& VÁrkonyi G. 2007: Occurrence of Psocoptera in boreal old-growth forests. - Entomol. Fenn. 18: 129-137.

Kentjonowati E.S. \& New T.R. 2004: Local diversity and ecological distribution of arboreal Psocoptera (Insecta) in Sumatra, Indonesia, and implications for conservation. - J. Insect Conserv. 8: 1-13.

Kozlov M.V., Nieukerken E.J. van, Zverev V. \& Zvereva E.L. 2013: Abundance and diversity of birch-feeding leafminers along latitudinal gradients in Northern Europe. - Ecography 36: $1138-1149$.

Laine A., ItÄmies J. \& Orell M. 1993: The Psocoptera of Norway spruce (Picea abies) branches in northern Finland. Entomol. Fenn. 4: 201-206.

Lienhard C. 1977: Die Psocopteren des Schweizerischen Nationalparks und seiner Umgebung (Insecta: Psocoptera). Ergeb. Wiss. Unters. Schweiz. Nationalpark 14: 417-551 (N.V.).

Moles A.T., Bonser S.P., Poore A.G.B., Wallis I.R. \& Foley W.J. 2011: Assessing the evidence for latitudinal gradients in plant defence and herbivory. - Funct. Ecol. 25: 380-388.

New T.R. 1970: Relative abundance of some British Psocoptera on different species of trees. - J. Anim. Ecol. 39: 521-540.

NIEMELÄ J. 1997: Invertebrates and boreal forest management. - Conserv. Biol. 11: 601-610.

Reuter O.M. 1893: Corrodentia Fennica. I. Psocidae. Förteckning och beskrifning öfver Finlands psocider. - Acta Soc. Fauna Flora Fenn. 9: 1-47.

SAveliev P.V. 1997: To the fauna of psocids (Insecta: Psocoptera) of Leningrad oblast. - Vest. St. Petersburg State Univ. (Ser. 3, Biol.) 3(17): 31-34 [in Russian].

SAVELIEV P.V. 1999: Materials to the fauna of psocids (Insecta: Psocoptera) of "Sevezhskij" National Park. - Nature of Pskov Region 9: 4-6 [in Russian].

SCHOwALTER T.D. 1989: Canopy arthropod community structure and herbivory in old-growth and regenerating forests in western Oregon. - Can. J. For. Res. 19: 318-322.

SCHOWALter T.D. 1995: Canopy arthropod communities in relation to forest age and alternative harvest practices in Western Oregon. - Forest Ecol. Manag. 78: 115-125.
Southwood T.R.E., Moran V.C. \& Kennedy C.E.J. 1982: The richness, abundance and biomass of the arthropod communities on trees. - J. Anim. Ecol. 51: 635-649.

Svensson B. \& Hall K. 2010: Nationalnyckeln till Sveriges flora och fauna. Stövsländor. Psocoptera. Artdatabanken, SLU, Uppsala, 204 pp. [in Swedish].

THornton I.W.B. 1985: The geographical and ecological distribution of arboreal Psocoptera. - Annu. Rev. Entomol. 30; 175-196.

Thunes K.H., Skartveit J., Guerde I., Stary J., Solhoy T., Fjellberg A., Kobro S., Nakahara S., zur Strassen R., Vierbergen G., Szadziewski R., Hagan D.V., Grogan W.L., Jonassen T., Aakra K., Anonby J., Greve L., Aukema B., Heller K., Michelsen V., Haenni J.P., Emeljanov A.F., Douwes P., Berggren K., Franzen J., Disney R.H.L., Prescher S., Johanson K.A., Mamaev B., Podenas S., Andersen S., GaImari S.D., NartshuK E., Soli G.E.E., Papp L., Midtgaard F., Andersen A., von Tschirnhaus M., Bachli G., Olsen K.M., Olsvik H., Foldvari M., RaAstad J.E., Hansen L.O. \& DJursVOLL P. 2004: The arthropod community of Scots pine (Pinus sylvestris L.) canopies in Norway. - Entomol. Fenn. 15: 65-90

Turner B.D. \& Broadhead E. 1974: The diversity and distribution of psocid populations on Mangifera indica L. in Jamaica and their relationship to altitude and microepiphyte diversity. - J. Anim. Ecol. 43: 173-190.

WATANABE H. \& RUAYSOONGNERN S. 1989: Estimation of arboreal arthropod density in a dry evergreen forest in Northeastern Thailand. - J. Tropical Ecol. 5: 151-158

Willig M.R., Kaufman D.M. \& Stevens R.D. 2003: Latitudinal gradients of biodiversity: pattern, process, scale and synthesis. - Annu. Rev. Ecol. Evol. Syst. 34: 273-309.

WoINARSKi J.C.Z. \& CUlLeN J.M. 1984: Distribution of invertebrates on foliage in forests of southeastern Australia. - Austral. J. Ecol. 9: 207-232.

Received January 3, 2013; revised and accepted August 7, 2013

APPENDIX. Species collecting data. The sites in the list (below) are labelled with a letter that indicates one of five gradients (consult Fig. 1), an approximate latitude $\left({ }^{\circ} \mathrm{N}\right)$ and preceded by abbreviated information on the geographical region (Ar - Arkhangelsk oblast; FIN - Finland; Ka - Republic of Karelia; Km Republic of Komi; Le - Leningrad oblast; Mu - Murmansk oblast; NOR - Norway; RUS - Russia; Vo - Vologda oblast); an asterisk $(*)$ denotes that the species has not yet been recorded from this region. A dash indicates that the species is also found in all sites located between those connected by a dash. Information on the plant(s), from which the species was collected, is shown in parentheses: syl-Pinus sylvestris; abi-Picea abies; pub-Betula pubescens; pen-B. pendula.

\section{Caeciliusidae}

Caecilius fuscopterus (Latreille). RUS. Ka: R63 (pen), R64 (syl, pen), R66 (syl, pub), R67 (pub).

Valenzuela burmeisteri (Brauer). FIN. F61 (syl, abi), F62-F63 (abi), F65-F66 (abi), F69 (abi). RUS. Le: R60 (abi); Ka*: R61 (abi), R63 (abi), R65-R67 (abi); Vo*: K59.1 (abi), K60 $(s y l)$.

V. despaxi (Badonnel). FIN. F61 (syl). NOR. N64 (abi).

$V$. flavidus (Stephens). FIN. F61 (pub), F67 (pub). NOR. N60 (pen). RUS. Le: R60 (abi, pub); Ka: R62 (pub), R64 (abi, pen), R65-R66 (abi), R67 (abi, pub); Mu*: R68 (abi, pen, pub), R69 (syl, abi, pub); Vo*: K59.1 (abi), K62 (pub).

V. gynapterus Tetens. RUS. Ka*: R61 (pub). 
V. piceus (Kolbe). RUS. Le: R60 (syl, abi); Ar*: A61.9-A62.7 (abi).

Enderleinella obsoleta (Stephens). RUS. Le: R60 (abi); Ka: R61 (abi), R67 (abi); Ar*: A60.5 (abi).

\section{Stenopsocidae}

Stenopsocus immaculatus (Stephens). RUS. Le: R60 (pen).

S. lachlani Kolbe: NOR. N69 (syl). RUS. Le: R60 ( $s y l$, abi, pen, pub); Ka*: R61 (abi), R64-R67 (abi); Mu*: R69 (abi); Vo*: K59.1 (abi).

\section{Peripsocidae}

Peripsocus phaeopterus (Stephens). RUS. Le: R60 (syl, abi); Ka*: R61 (pen, pub); Vo*: K60 (syl, abi).

P. subfasciatus (Rambur). RUS. Le: R60 (syl, abi, pen, pub); Ka*: R61 (abi), R62 (abi, syl, pub); Vo*: K60 (abi).

\section{Philotarsidae}

Philotarsus sp. RUS. Le: R60 (abi).

\section{Elipsocidae}

Elipsocus abdominalis Reuter. FIN. F61 (pen). RUS*. Ka*: R65 (pen).

Hemineura dispar Tetens. RUS. Ka: R65 (syl, pen).

\section{Mesopsocidae}

Mesopsocus unipunctatus (Muller). RUS. Ka: R67 (pub); Mu*: R69 (pub).

M. immunis (Stephens). NOR. N63 (pub).

\section{Psocidae}

Psococerastis gibbosa (Sulzer). RUS. Ka*: R62 (pen).

Metylophorus nebulosus (Stephens). FIN. F64 (pen). RUS. Ka: R61 (syl, abi), R64 (syl, pen, pub).

Trichadenotecnum majus (Kolbe): RUS. Ka: R66 (abi).

T. incognitum Roesler: RUS. Km*: K65.1 (abi). 